\title{
Comparative introduction study of Syringa vulgaris $L$. cultivars in the conditions of a moderately continental, continental and conditionally subtropical climate of the Mediterranean type
}

\author{
Vera Zykova ${ }^{1 *}$, Anastasia Belanova ${ }^{2}$, Elena Vinogradova $^{3}$, Svetlana Prihodko ${ }^{3}$ and \\ Svetlana Plugatar ${ }^{1}$ \\ ${ }^{1}$ Nikita Botanical Gardens - National Scientific Center of the RAS, 298648 Yalta, Russia \\ ${ }^{2}$ Central Siberian Botanical Garden SB RAS, 630090 Novosibirsk, Russia \\ ${ }^{3}$ Donetsk Botanical Garden, 283059 Donetsk, DPR
}

\begin{abstract}
The article presents the results of a comparative introduction study and cultivar evaluation of 7 of common lilac cultivars in the collections of three botanical gardens (the Nikita Botanical Gardens, the Central Siberian Botanical Garden and the Donetsk Botanical Garden) located in zones with conditionally subtropical, temperate continental and continental climate. It is established that the cultivars retain their decorative features in the conditions of introduction and show ecological plasticity, increasing their growing season with an increase in the vegetation period, as well as reducing the area of the leaf blade with a decrease in the average annual precipitation.
\end{abstract}

Syringa vulgaris $\mathrm{L}$. and cultivars created on the basis of this species are among the most popular beautiful-flowering shrubs. Introduction of lilac is carried out in many botanical institutions, including the Nikita Botanical Gardens (Russia, Yalta), the Central Siberian Botanical Garden (Russia, Novosibirsk) and the Donetsk Botanical Garden (DNR, Donetsk). These botanical gardens are located in different climatic zones, and therefore a comparative study of the growth and development rhythms of lilac cultivars, as well as their comparative cultivar assessment, is of great interest.

Nikita Botanical Gardens (NBG) is located on the Southern Coast of the Crimea (SCC) in a zone with a conditionally subtropical Mediterranean climate [1]. The main climatic features here are very mild winters and dry moderately hot summers, the predominance of precipitation in the cold period of the year (from November to March). The average annual precipitation is $589 \mathrm{~mm}$. The species Syringa vulgaris L. was introduced to the NBG in 1813 , and then its forms and cultivars were introduced, as well as other species of the genus Syringa. At this time, 80 species, cultivars and forms are being introduced.

Donetsk Botanical Garden (DBG) is located in the steppe zone, characterized by a moderately continental climate with sharp fluctuations in air temperature, low humidity,

* Corresponding author: zykova@mail.com 
uneven seasonal distribution and significant year-by-year fluctuations in precipitation (from 223 to $655 \mathrm{~mm}$ ), frequent soil and atmospheric droughts. The region is also characterized by a high level of environmental pollution due to a significant concentration of environmentally hazardous industrial enterprises. Under the influence of unfavorable environmental and climatic conditions, the xeromorphic structure of leaves prevails in woody plants [2].

The formation of the collection of the genus Syringa in the DBG was started in 1970, when about $100 \mathrm{~S}$. vulgaris bushes were planted in the arboretum in the collection of the Oleaceae family, and other species of the genus were planted in the following years. In 1978, the Syringa collection and exposition site ("Syringariy") was established, on the territory of which 12 species, 4 subspecies and 6 forms of the genus Syringa, as well as 140 cultivars, mainly $S$. vulgaris, currently grow.

Central Siberian Botanical Garden (CSBG, Siberian Branch of the RAS) is located in the forest-steppe zone of the south of Western Siberia and is characterized by a continental climate. The duration of the winter period here is about 155-160 days from the first days of November to the end of March, the average temperature is $-19^{\circ} \mathrm{C}$. The spring period is characterized by a rapid increase in positive temperatures, but in the second half of May there is a return of cold weather, late spring frosts. The average annual precipitation is 460 $\mathrm{mm}$ [3].

In 1986, Laboratory of dendrology at the CSBG started of introduction work with $S$. vulgaris cultivars in order to create a collection of the most promising cultivars for the continental climate of the forest-steppe zone of Western Siberia. During the period of work, 126 cultivars of foreign and domestic selection were tested. Currently, there are 26 cultivars of common lilac cultivars in the collection, recommended for landscaping of Siberian cities [4]

The objects of research in this work were 7 cultivars of S. vulgaris common to the three mentioned collections: 'Katherine Havemeyer' (Lemoine, 1922), 'Krasavitsa Moskvy' (Kolesnikov 1947), 'Mme Lemoine' (Lemoine, 1928), 'Nadezhda' (Kolesnikov, 1968), 'Ogni Donbassa' (Rubtzov, Zhogoleva, Lyapunova, 1956), 'Olimpiada Kolesnikova' (Kolesnikov, 1941), 'Sensation' (Maarse, 1938). The studies were conducted according to generally accepted methods.

The results of a comparative study of the time and duration of the growing season and the flowering period of cultivars are presented in Table 1.

The beginning of the growing season of lilac cultivars in the NBG falls on the third decade of February - the first decade of March, and the end - at the end of October - the second half of November. The average duration of the growing season ranges from 241 days for 'Sensation' cultivar to 259 days for 'Katherine Havemeyer' cultivar. 'Katherine Havemeyer' and 'Nadezhda' cultivars bloom early, have a maximum flowering duration (21-28 days) and have a period of premature flowering in autumn. The beginning of the growing season of $S$. vulgaris and its cultivars in the DBG falls on the first-second decade of March. The average duration of the vegetation period of the analysed cultivars is 220 days, the maximum is typical for 'Katherine Havemeyer' cultivar (227 days). The flowering phase of the analysed cultivars begins in the first decade of May and lasts 18-25 days. The longest flowering time (more than 20 days) is typical for the cultivars 'Katherine Havemeyer' and 'Nadezhda'.

The beginning of the growing season of common lilac cultivars in the CSBG falls on the third decade of April - the first decade of May, and the end on the third decade of September - the beginning of October. The vegetation period ranges from 148 days for 'Sensation' cultivar to 162 days for 'Katherine Havemeyer' cultivar. Due to the climatic features of the spring period (a rapid increase in positive temperatures), the difference in the terms of vegetation and the duration of flowering of the analysed cultivars is insignificant 
and amounts to 1-3 days. However, the cultivars 'Katherine Havemeyer', 'Krasavitsa Moskvy' and 'Ogni Donbassa' bloom earlier and have a longer flowering period (19-21 days). The cultivars 'Nadezhda', 'Mme Lemoine', 'Olimpiada Kolesnikova' and 'Sensation' start blooming 2-4 days later and bloom for less extended time.

Table 1. Phenological characteristic of lilac cultivars in the conditions of introduction.

\begin{tabular}{|c|c|c|c|}
\hline \multirow{2}{*}{ Cultivar } & \multicolumn{3}{|c|}{$\begin{array}{c}\text { Time of the beginning and end of the growing season / } \\
\text { Time of the beginning and end of flowering }\end{array}$} \\
\hline & NBG & DBG & CSBG \\
\hline 'Katherine Havemeyer' & $\begin{array}{l}\text { 3.III-17.XI / } \\
14 . \mathrm{IV}-10 . \mathrm{V}\end{array}$ & $\begin{array}{c}\text { 9.III-21.X / } \\
3 . \mathrm{V}-27 . \mathrm{V}\end{array}$ & $\begin{array}{l}\text { 30. IV-9.X / } \\
\text { 28.V-14.VI }\end{array}$ \\
\hline 'Krasavitsa Moskvy' & $\begin{array}{l}\text { 7.III-5.XI / } \\
\text { 28.IV-13.V }\end{array}$ & $\begin{array}{l}\text { 12.III-9.X / } \\
\text { 5.V-22.V }\end{array}$ & $\begin{array}{l}\text { 26. IV-2.X / } \\
\text { 29.V-17.VI }\end{array}$ \\
\hline 'Mme Lemoine' & $\begin{array}{l}26 . \mathrm{II}-5 . \mathrm{XI} / \\
5 . \mathrm{V}-17 . \mathrm{V}\end{array}$ & $\begin{array}{l}\text { 6.III-16.X / } \\
9 . \mathrm{V}-28 . \mathrm{V}\end{array}$ & $\begin{array}{c}\text { 30. IV-27.IX/ } \\
\text { 30.V-16.VI }\end{array}$ \\
\hline 'Nadezhda' & $\begin{array}{l}\text { 23.II-2.XI / } \\
11 . \mathrm{IV}-9 . \mathrm{V}\end{array}$ & $\begin{array}{l}\text { 5.III-16.X / } \\
5 . \mathrm{V}-25 . \mathrm{V}\end{array}$ & $\begin{array}{l}\text { 30. IV-29.IX / } \\
\text { 30.V-15.VI }\end{array}$ \\
\hline 'Ogni Donbassa' & $\begin{array}{l}\text { 8.III-9.XI / } \\
\text { 22.IV-12.V }\end{array}$ & $\begin{array}{l}\text { 12.III-21.X/ } \\
\text { 7.V-25.V }\end{array}$ & $\begin{array}{l}\text { 26. IV-3.X / } \\
\text { 28.V-17.VI }\end{array}$ \\
\hline 'Olimpiada Kolesnikova' & $\begin{array}{l}\text { 4.III-3.XI / } \\
\text { 21.IV-9.V }\end{array}$ & $\begin{array}{l}\text { 7.III-8.X / } \\
\text { 8.V-25.V }\end{array}$ & $\begin{array}{l}\text { 30. IV-28.IX / } \\
\text { 30.V-14.VI }\end{array}$ \\
\hline 'Sensation' & $\begin{array}{l}\text { 9.III-5.XI / } \\
\text { 29.IV-14.V }\end{array}$ & $\begin{array}{l}\text { 14.III-21.X } / \\
\text { 9.V-27.V }\end{array}$ & $\begin{array}{l}\text { 30. IV-25.IX / } \\
\text { 31.V-14.VI }\end{array}$ \\
\hline
\end{tabular}

A comparison of cultivars at different points of introduction according to some morphometric characteristics is presented in Table 2. It should be noted that significant differences were found for all cultivars and not for all analysed parameters.

Table 2. Morphometric parameters of lilac cultivars in the conditions of introduction.

\begin{tabular}{|c|c|c|c|c|}
\hline \multirow{4}{*}{ Cultivar } & Parameters & NBG & DBG & CSBG \\
\hline \multirow{4}{*}{$\begin{array}{c}\text { 'Katherine } \\
\text { Havemeyer' }\end{array}$} & Flower diameter, cm & $3.00 \pm 0.05$ & $3.08 \pm 0.23$ & $2.68 \pm 0.06$ \\
\cline { 2 - 5 } & Number of corollas & up to 2.5 & up to 2.5 & up to 2.5 \\
\cline { 2 - 5 } & $\begin{array}{c}\text { Inflorescence length, cm } \\
\text { The number of flowers in the } \\
\text { inflorescence }\end{array}$ & $20.26 \pm 3.21$ & $19.00 \pm 2.45$ & $13.8 \pm 0.49$ \\
\cline { 2 - 5 } & $\begin{array}{c}\text { Number of pairs of } \\
\text { generative buds }\end{array}$ & $1-2$ & $1-2$ & $100 \pm 14$ \\
\cline { 2 - 5 } & $\begin{array}{c}\text { Area of a leaf blade, cm } \\
\text { Flower diameter, cm }\end{array}$ & $53.37 \pm 9.75$ & $21.27 \pm 7.61$ & $45.5 \pm 4.92$ \\
\hline \multirow{4}{*}{$\begin{array}{c}\text { 'Krasavitsa } \\
\text { Moskvy' }\end{array}$} & Number of corollas & up to 3 & up to 2.5 & up to 3 \\
\cline { 2 - 5 } & Inflorescence length, cm & $23.66 \pm 4.16$ & $17.20 \pm 1.30$ & $18.33 \pm 1.65$ \\
\cline { 2 - 5 } & $\begin{array}{c}\text { The number of flowers in the } \\
\text { inflorescence }\end{array}$ & $143 \pm 12$ & $93 \pm 7$ & $119 \pm 15$ \\
\cline { 2 - 5 } & $\begin{array}{c}\text { Number of pairs of } \\
\text { generative buds }\end{array}$ & $1-2$ & $1-2$ & $1-2$ \\
\cline { 2 - 5 } & Area of a leaf blade, cm & $56.93 \pm 14.15$ & $30.35 \pm 6.73$ & $39.45 \pm 3.39$ \\
\hline
\end{tabular}




\begin{tabular}{|c|c|c|c|c|}
\hline \multirow{6}{*}{ 'Mme Lemoine' } & Flower diameter, $\mathrm{cm}$ & $2.46 \pm 0.13$ & $2.44 \pm 0.20$ & $1.97 \pm 0.3$ \\
\hline & Number of corollas & up to 2 & up to 2,5 & up to 2 \\
\hline & Inflorescence length, $\mathrm{cm}$ & $15.01 \pm 4.60$ & $17.75 \pm 2.54$ & $15.5 \pm 1.76$ \\
\hline & $\begin{array}{l}\text { The number of flowers in the } \\
\text { inflorescence }\end{array}$ & $85 \pm 22$ & $136 \pm 20$ & $143 \pm 19$ \\
\hline & $\begin{array}{c}\text { Number of pairs of } \\
\text { generative buds }\end{array}$ & 1 & 1 & 1 \\
\hline & Area of a leaf blade, $\mathrm{cm}^{2}$ & $50.32 \pm 13.20$ & $22.63 \pm 5.39$ & $32.98 \pm 8.568$ \\
\hline \multirow{6}{*}{ 'Nadezhda' } & Flower diameter, $\mathrm{cm}$ & $3.06 \pm 0.27$ & $2.72 \pm 0.27$ & $2.89 \pm 0.12$ \\
\hline & Number of corollas & up to 2.5 & up to 2.5 & up to 2.5 \\
\hline & Inflorescence length, $\mathrm{cm}$ & $19.40 \pm 2.96$ & $16.3 \pm 3.62$ & $15.5 \pm 1.47$ \\
\hline & $\begin{array}{c}\text { The number of flowers in the } \\
\text { inflorescence }\end{array}$ & $107 \pm 14$ & $120 \pm 18$ & $118 \pm 17$ \\
\hline & $\begin{array}{l}\text { Number of pairs of } \\
\text { generative buds }\end{array}$ & 1 & 1 & 1 \\
\hline & Area of a leaf blade, $\mathrm{cm}^{2}$ & $34.01 \pm 9.46$ & $21.36 \pm 7.95$ & $40.7 \pm 6.5$ \\
\hline \multirow{6}{*}{ 'Ogni Donbassa' } & Flower diameter, $\mathrm{cm}$ & $2.01 \pm 0.03$ & $2.62 \pm 0.28$ & $1.97 \pm 0.02$ \\
\hline & Number of corollas & up to 3 & up to 3 & up to 3 \\
\hline & Inflorescence length, $\mathrm{cm}$ & $19.60 \pm 3.78$ & $15.25 \pm 2.21$ & $16.7 \pm 1.76$ \\
\hline & $\begin{array}{l}\text { The number of flowers in the } \\
\text { inflorescence }\end{array}$ & $145 \pm 54$ & $116 \pm 25$ & $113 \pm 31$ \\
\hline & $\begin{array}{l}\text { Number of pairs of } \\
\text { generative buds }\end{array}$ & 1 & 1 & 1 \\
\hline & Area of a leaf blade, $\mathrm{cm}^{2}$ & $43.03 \pm 10.15$ & $32.08 \pm 8.17$ & $41.89 \pm 5.63$ \\
\hline \multirow{6}{*}{$\begin{array}{l}\text { 'Olimpiada } \\
\text { Kolesnikova' }\end{array}$} & Flower diameter, $\mathrm{cm}$ & $2.50 \pm 0.05$ & $2.72 \pm 0.72$ & $1.8 \pm 0.06$ \\
\hline & Number of corollas & up to 3 & up to 2 & up to 3 \\
\hline & Inflorescence length, $\mathrm{cm}$ & $20.40 \pm 7.60$ & $16.75 \pm 1.48$ & $13.6 \pm 1.47$ \\
\hline & $\begin{array}{c}\text { The number of flowers in the } \\
\text { inflorescence }\end{array}$ & $123 \pm 36$ & $105.67 \pm 26.3$ & $84 \pm 17$ \\
\hline & $\begin{array}{l}\text { Number of pairs of } \\
\text { generative buds }\end{array}$ & $1-2$ & $1-2$ & $1-2$ \\
\hline & Area of a leaf blade, $\mathrm{cm}^{2}$ & $43.31 \pm 13.97$ & $22.51 \pm 6.43$ & $35.53 \pm 4.15$ \\
\hline \multirow[t]{4}{*}{ 'Sensation' } & Flower diameter, $\mathrm{cm}$ & $2.04 \pm 0.07$ & $2.37 \pm 0.16$ & $1.94 \pm 0.04$ \\
\hline & Number of corollas & 1 & 1 & 1 \\
\hline & Inflorescence length, $\mathrm{cm}$ & $16.03 \pm 2.55$ & $16.00 \pm 1.87$ & $14.4 \pm 0.62$ \\
\hline & $\begin{array}{c}\text { The number of flowers in the } \\
\text { inflorescence }\end{array}$ & $89 \pm 24$ & $101.6 \pm 21.6$ & $111 \pm 27$ \\
\hline
\end{tabular}




\begin{tabular}{|c|c|c|c|c|}
\hline & $\begin{array}{c}\text { Number of pairs of } \\
\text { generative buds }\end{array}$ & 1 & 1 & 1 \\
\cline { 2 - 5 } & Area of a leaf blade, $\mathrm{cm}^{2}$ & $23.95 \pm 3.62$ & $26.12 \pm 8.05$ & $28.77 \pm 2.37$ \\
\hline
\end{tabular}

There were no significant differences in the main indicators describing the decorative value of the analysed cultivars, such as the duration of flowering, the structure and size of flowers and inflorescences, however, the greatest variability in the length of inflorescences and their slightly larger average sizes were noted under the conditions of the SCC. The decrease in the area of the leaf blade noted in most cultivars under the DBG conditions is apparently associated with a decrease in the amount of precipitation and is a xeromorphic trait, which also indicates the ecological plasticity of common lilac cultivars. The studied cultivars are well known and popular. Our studies have shown that they retain their decorative effect when introduced in various climatic zones.

The work was carried out within the framework of the state assignments No0829-2019-0034 of the Nikita Botanical Gardens - National Scientific Center of the RAS and No AAAA-A21121011290027-6 of the Central Siberian Botanical Garden of the SB RAS with material of CSBG representing USFs (Unique Scientific Facilities) "Collections of living plants indoors and outdoors" USU 440534.

\section{References}

1. V. V. Antyufeev, R. N. Kazimirova, A. P. Yevtushenko, Collection of scientific works of the State Nikitsky Botanical Gardens 137 (2014)

2. A. K. Polyakov, Introduction of woody plants in a technogenic environment (Knowledge, Donetsk, 2009)

3. L. N. Chindyaeva, M. A. Tomoshevich, A. P. Belanova, E. V. Banaev, Woody plants in the landscaping of Siberian cities (Geo, Novosibirsk, 2018)

4. E. M. Lyakh, Scientific Journal of KubSAU 10(154) (2019) 